\title{
Population Exchange and the Politics of Ethno-Religious Fear: the EU-Turkey Agreement on Syrian Refugees in Historical Perspective
}

\author{
Gregory J. Goalwin \\ Department of Sociology, \\ University of California, Santa Barbara \\ Santa Barbara, CA, U.S.A.
}

\begin{abstract}
:
In March of 2016 the EU and Turkey reached an agreement in which all refugees who reach Greece through unauthorized means would be returned to Turkey. The deal is the latest effort to 'stem the tide' of refugees who have fled the Middle East. Yet this is not the first time negotiations between Europe and Turkey have resulted in an agreement to exchange problematic populations. As part of the negotiations ending WWI, Turkey and Europe agreed to a transfer of populations in which Christians in Turkey would be sent to Greece in exchange for Greece's small population of Muslims. This project draws upon historical research and contemporary policy analysis to compare the 2016 EU-Turkey Refugee Agreement and the 1923 GrecoTurkish population exchange. A comparative approach reveals the European response to this refugee crisis is not merely an echo of past sentiments, but the product of patterns of prejudice that have structured relationships between majority populations and religious minority and refugee populations in Europe and Turkey alike.
\end{abstract}

\section{Keywords:}

Population Exchange; Refugee Crisis; Syria; Turkey; European Union; EU-Turkey Agreement on

Refugees

\section{Biographical Note:}

Gregory Goalwin holds a Ph.D. in Sociology from the University of California, Santa Barbara and currently serves as Lecturer at California State University, Channel Islands. His research examines religion, culture, and the formation of ethnic and national identity, with particular focus on Ireland and the early years of the Republic of Turkey. 


\section{Population Exchange and the Politics of Ethno-Religious Fear: the EU-Turkey Agreement on Syrian Refugees in Historical Perspective}

On March 18, 2016, leaders of the European Union and the Republic of Turkey reached an agreement specifying that all new refugees who arrived in Greece through unauthorized means would be returned to Turkey. The deal was the latest effort to 'stem the tide' of refugees who have fled violence in the Middle East, civil war in Syria, and the rise of the Islamic State, passing through Turkey and into the EU. Under the agreement, the EU agreed to accept one Syrian from a refugee camp in Turkey in exchange for every unauthorized migrant transported back there, a resettlement process designed to channel refugees away from hazardous trips across the Aegean and towards safer and more controlled methods. Ostensibly a humanitarian effort to protect refugee lives, the plan was met with immediate protests from human rights organizations. Amnesty International called it 'a historic blow to human rights,' ${ }^{1}$ the UN High Commissioner for Refugees raised questions about the mechanics of asylum requests and the exchange process, ${ }^{2}$ and Doctors Without Borders labeled it 'inhumane.' ${ }^{3}$ Both the UNHCR and Doctors Without Borders withdrew their staff from refugee camps in Greece in protest, arguing that continued relief efforts would make them complicit in a process that might be illegal under international law and which 'has no regard for the humanitarian or protection needs of asylum seekers and migrants. ${ }^{4}$

Yet this is not the first time that negotiations between Europe and Turkey have resulted in an agreement to exchange problematic populations of those considered foreign. In 1923, a peace treaty signed in Lausanne, Switzerland ended conflict between Turkey and the Allied Powers of WWI and recognized Turkey as a sovereign state. The treaty contained an agreement that provided for the mandatory resettlement of all Greek Orthodox Christians living in the territory of the new Turkey and their exchange for the small population of Muslims living in Greece. This religious 'unmixing' was designed to promote national homogenization, creating Turkish and Greek populations that would be free of 'dangerous' minority populations and thus lessen the potential for ethnic and religious conflict within the two countries. In its final form, this exchange, too, was advertised as the best way to protect imperiled populations, providing a humanitarian solution for minority populations who suddenly found themselves on the wrong side of national boundaries.

This article draws upon historical research and contemporary policy analysis to compare the 2016 EU-Turkey Agreement on Refugees and the 1923 Greco-Turkish population exchange. Though separated by nearly a century, the two agreements share striking similarities. Both the 1923 exchange and the 2016 agreement represented efforts to craft an international response to

\footnotetext{
${ }^{1}$ Amnesty International, 'EU-Turkey Refugee Deal a Historic Blow to Rights [Press Release],' March 18, 2016, www.amnesty.org/en/press-releases/2016/03/eu-turkey-refugee-deal-a-historic-blow-to-rights/.

${ }^{2}$ United Nations High Commissioner for Refugees, 'UNHCR on EU-Turkey Deal: Asylum Safeguards Must Prevail in Implementation [Press Release],' March 18, 2016, www.unhcr.org/56ec533e9.html.

${ }^{3}$ Doctors Without Borders, 'European Union and Turkey Reach Inhumane Agreement on Refugees [Press Release],' March 8, 2016, www.doctorswithoutborders.org/article/european-union-and-turkey-reach-inhumane-agreementrefugees.

${ }^{4}$ Doctors Without Borders, 'Greece: MSF Ends Activities at Primary Lesvos Transit Camp,' March 22, 2016, www.doctorswithoutborders.org/article/greece-msf-ends-activities-primary-lesvos-transit-camp.
} 
massive waves of migration from the Middle East to Europe. In both cases, Turkey and Europe (represented variously by the League of Nations and the EU) sought to negotiate a compromise that would mitigate a growing refugee crisis while maximizing political advantage. In both 1923 and 2016, European and Turkish leaders presented the agreements as political and humanitarian victories that would protect the lives of minorities and refugees and lead to a greater era of peace and understanding. In both cases, however, concerns for the human beings involved took a back seat to geopolitical bargain-making. Most importantly, both exchanges were the end result of a politics of fear, the consequence of concerns over the presence of a religious other, and driven as much by an impulse for homogeneity as any true humanitarian goals.

The many similarities between these two cases makes a comparative approach instructive. Traditional comparative-historical sociology often focuses on isolated cases, seeking to use particular instances of a given phenomenon as discreet events. ${ }^{5}$ This method has advantages in that it allows analysts to isolate the causal variables that drive social events. ${ }^{6}$ Yet analyses that examine events in different contexts often pay less attention to the temporal dimension of social phenomena, the ways in which structures, institutions, and social practices function across history. Sociologists interested in the historical dimension of social phenomena have responded to this lack of engagement with temporality by developing methodologies designed to reveal the ways in which earlier events impact social phenomena. Approaches such as narrative analysis, ${ }^{7}$ path-dependency theory, ${ }^{8}$ and reiterated problem solving, ${ }^{9}$ "allow us to situate events in a context of relevant larger-scale and longer-term processes." 10 As Jeffrey Haydu has argued, "the methodological goal should be to treat outcomes in different eras as parts of an intelligible sequence and recognize that past problems and solutions have cumulative influences on later ones." "In our case, examining European and Turkish responses to refugee crises in two different time periods does just that, adding an important chronological variable that allows us to see the historical patterns of interaction that continue to guide policy decisions today.

This analysis borrows elements from these techniques to compare the two exchanges. In keeping with the reiterative problem-solving approach, I view both agreements as examples of a single phenomenon: products of political problem-solving seeking solutions for large-scale refugee movements. Though there is little evidence that negotiations in 2016 drew upon earlier examples, both agreements reflected a similar logic and reinforced the trajectory of historical relationships between Turkey, Europe, and refugee populations moving between the two. Similarly, I draw from path-dependency a focus on what James Mahoney refers to as selfreinforcing sequences, ${ }^{12}$ processes by which given institutional patterns are formed, reproduced, and entered into social and political memory over the long-term. In this case, those patterns were

\footnotetext{
${ }^{5}$ Ronald Aminzade, "Historical Sociology and Time," Sociological Methods \& Research 20, no. 4 (May 1992 ): 457.

6 Theda Skocpol and Somers Margaret, "The Uses of Comparative History in Macrosocial Inquiry," Comparative Studies in Society and History 22, no. 2 (1980): 175.

${ }^{7}$ Margaret R. Somers, "The Narrative Constitution of Identity: A Relational and Network Approach," Theory \& Society 23, no. 5 (1994).

8 James Mahoney, "Path Dependence in Historical Sociology," Theory and Society 29, no. 4 (2000): 507-48.

9 Jeffrey Haydu, "Making Use of the Past: Time Periods as Cases to Compare and as Sequences of Problem Solving," American Journal of Sociology 104, no. 2 (1998): 339-71.

${ }^{10}$ Aminzade, "Historical Sociology and Time," 458.

${ }^{11}$ Haydu, "Making Use of the Past," 360.

12 Mahoney, "Path Dependence in Historical Sociology," 508.
} 
ones of exclusion and exchange, arrangements that tell an important story about how European and Turkish identity and politics are structured. Indeed, it is identity and the relationship between resident and immigrant populations that lie at the core of both exchanges. Finally, with narrative analysis, I share an emphasis on the stories people and societies tell about themselves and the ways such narratives help shape group identity. Collective identities are often produced by narratives, methods of organizing historical events that draw important boundary lines between in-groups and out-groups, adding meaning and weight to self-conceptions of identity. ${ }^{13}$

Crucially, it is these narratives that give us insight into the decision-making processes that led to both agreements. The Eastern Mediterranean is a diverse region, home to a wide array of ethnic and religious populations that have coexisted for centuries. Despite this, or perhaps because of it, civilizational narratives have long sought to draw distinctions between Europe and the Middle East, crafting ontological stories that draw from historical patterns of collective memory to inscribe boundary lines differentiating members of one group from the next. The formation of group boundaries has been the subject of a large body of sophisticated scholarly work. ${ }^{14}$ Researchers working in this vein have argued that conceptions of identity are often forged through interaction with outsiders, defined in opposition to those deemed different. In their close proximity and constant interaction, Europe and Turkey have often found in each other a 'significant other,' a threatening opponent in opposition to which identity could form. ${ }^{15}$ The result has thus been conceptions of identity in both Europe and Turkey that promote a sense of homogeneity, crafting ethnic and civilization boundaries that create distinct in-groups and outgroups, most often centered on religious difference. The narrative construction of European identity, in particular, has placed a heavy premium on its Christian inheritance, and it is no accident that both exchanges have entailed a component designed to purge Muslims from Europe. ${ }^{16}$ Turkey also has a long history of ethnic and religious exclusion, however, as Turkish nationalists have worked to create a distinct and exclusive form of Turkish nationhood. ${ }^{17} \mathrm{By}$ passing from Syria, through Turkey, to Europe, refugees complicate these distinctions and force interaction between previously differentiated populations. In this regard, negotiations over the fate of refugees and migrants crossing the Aegean has repeatedly provided an arena in which ethnic and civilizational boundaries, conceptions of identity, and difference are determined and reinforced on the ground.

Both population exchanges reveal evidence of such boundary-making processes at work. Conceptions of 'the Muslim World' and 'Christendom,' are ancient, dating back far further than

\footnotetext{
${ }^{13}$ Somers, "The Narrative Constitution of Identity: A Relational and Network Approach."

${ }^{14}$ Fredrik Barth, "Introduction," in Ethnic Groups and Boundaries. The Social Organization of Culture Difference. (Boston: Little, Brown, 1969); Michele Lamont and Virag Molnar, "The Study of Boundaries in the Social Sciences," Annual Review of Sociology 28 (2002); Rogers Brubaker, Ethnicity without Groups (Cambridge, Mass.: Harvard University Press, 2004); Andreas Wimmer, Ethnic Boundary Making : Institutions, Power, Networks (New York: Oxford University Press, 2013); Gregory J. Goalwin, "Understanding the Exclusionary Politics of Early Turkish Nationalism: An Ethnic Boundary-Making Approach," Nationalities Papers, June 12, 2017, 1-17.

${ }^{15}$ A. Triandafyllidou, "National Identity and the 'Other,'” Ethnic and Racial Studies 21, no. 4 (July 1998): 593-612.

${ }^{16}$ Samuel P. Huntington, The Clash of Civilizations and the Remaking of World Order (New York: Simon \& Schuster, 1996); Talal Asad, "Muslims and European Identity: Can Europe Represent Islam?," in Cultural Encounters: Representing Otherness, ed. Elizabeth Hallam and Brian V. Street (Routledge, 2013); Sami Zubaida, "Islam in Europe," Critical Quarterly 45, no. 1-2 (2003): 88-98.

${ }^{17}$ Gregory J. Goalwin, “'Religion and Nation Are One': Social Identity Complexity and the Roots of Religious Intolerance in Turkish Nationalism," Social Science History, Forthcoming.
} 
1923. The population exchange between Greece and Turkey, coming as it did at a crucial historical moment during the end of WWI, however, played a particularly powerful role in codifying these distinctions. ${ }^{18}$ Indeed, in its decision to separate populations of Muslims and Christians that had coexisted for centuries, the Greco-Turkish population exchange reified a pattern of group identification that relied heavily upon religious affiliation to create a distinct and exclusionary boundary between Christian Europe and a Muslim Middle East. In this, the population exchange helped solidify institutionalized patterns of civilizational difference, a selfreinforcing sequence that built on earlier conceptions of identity and which has had far-reaching effects. While significant populations of Muslims still live in Europe and Christians in the Middle East, the idea of homogeneity and difference has helped structure what it means to be European or Middle Eastern. Extant minority populations thus serve only to highlight the role of group identity and the ways in which religious affiliation serves as a marker of outsider status. ${ }^{19}$ In this light, the European response to the modern refugee crisis can be seen as the latest effort to reinforce these boundaries, born of a politics that places a powerful emphasis on ethno-religious concerns. The EU-Turkey Agreement on Refugees thus represents not merely an echo of past sentiments. Instead, it reveals patterns of prejudice that have structured relationships between majority and minority populations in the Eastern Mediterranean for almost a century.

\section{The Greco-Turkish Population Exchange}

In the turmoil that surrounded the Ottoman Empire's defeat and collapse, European powers partitioned the Empire's territory, dividing it amongst themselves. This partitioning process culminated in a Greek invasion of Western Anatolia as Greece tried to assert control over land it had been granted. Despite initial successes, the result was a devastating defeat, referred to as the Asia Minor Catastrophe in Greece. The Greek army was driven out by a Turkish revolutionary movement, but it left significant problems in its wake. Large populations of Greek Orthodox Christians had lived in western Anatolia for centuries as citizens of the Ottoman Empire. With the rise of nationalism and the aid some Greek Orthodox residents gave to the invading Greek army this population was thought to be suspect and disloyal, a 'foreign' religious minority, not proper material on which to build a new Turkish nation. This antipathy was matched by the sentiments many Christians in Greece felt for the Muslims in their midst, who were viewed as a remnant of the Ottoman rulers from whom they had won their independence. As part of the peace negotiations the parties agreed to an enforced transfer of populations in Christians would be removed from the new Turkey, sent to Greece in exchange for Greece's small population of suspect Muslims.

In many ways, the population exchange between Greece and Turkey represented the end of an era of cultural and religious tolerance. The social and political framework of the Ottoman system, a multi-religious and multi-ethnic polity, was such that people's religious faith determined their position in society, the avenues available to them, and the people they came into contact with on a daily basis. ${ }^{20}$ This social organization along religious grounds helped determine

\footnotetext{
${ }^{18}$ Bruce Clark, Twice a Stranger: The Mass Expulsions That Forged Modern Greece and Turkey (Cambridge, Mass.: Harvard University Press, 2006).

${ }^{19}$ Barth, "Introduction"; Tariq Modood, Anna Triandafyllidou, and Ricard Zapata-Barrero, Multiculturalism, Muslims and Citizenship: A European Approach (Routledge, 2006).

${ }^{20}$ Ronald Grigor. Suny, "They Can Live in the Desert but Nowhere Else": A History of the Armenian Genocide (Princeton, N.J.: Princeton University Press, 2015), 46.
} 
the most salient characteristic of identity in the everyday lives of the Ottoman population. People conceived of themselves as being 'Christian' or 'Muslim' rather than being 'Turkish' or 'Greek.' Though Muslim populations were privileged in the Ottoman system, numerous sources testify to relatively good relations between Christian and Muslim communities. Some Christians went so far as to say that 'Before [World War I] we lived well with the Turks. We got on like brothers' and mutual concerns of village life led to strong intercommunal bonds and deep friendships across religious lines. ${ }^{21}$ For much of late Ottoman history, then, intercultural relationships were largely positive. Christians, Jews, and Muslims lived side by side within the Ottoman framework, and religious minorities were treated far better in the Ottoman Empire than were minorities in Western Europe. ${ }^{22}$

Though the Ottoman Empire provided a framework in which Muslims, Christians, and Jews were able to get along peacefully, if not overly equitably, in Anatolia, events on the world stage would soon conspire to strain the relationships that guaranteed intercommunal civility. The rise of nationalism in Western Europe spread quickly, and Christian populations in the Balkans rose up against the Ottoman Empire. The Ottomans lost most of their territory in Europe in 1912 and 1913, as Balkan states waged successful wars to reintegrate ethnic populations who still fell under Ottoman rule into their respective national states. The violence that accompanied the Ottoman Empire's loss of its European colonies brought with it a wave of human misery as communities were polarized by national conflict expressed in religious terms. Christians often used their victory as an opportunity to pay back the Ottomans for what they saw as centuries of oppression. Such targeted violence had vast repercussions. Millions of Muslim refugees fled the former Ottoman possessions in the Balkans for safer conditions deeper within the Ottoman Empire. ${ }^{23}$ The Muslims who arrived in Anatolia brought with them heartbreaking stories of Christian campaigns of brutality. Intercommunal tensions in Anatolia, already strained by war and the perceptible decline of the Ottoman Empire, ratcheted ever higher and the influx of Muslim refugees from the Balkans and the perceived demise of the Empire polarized Ottoman society. Religious identities, which had long been markers of relatively benign difference acquired an increasingly political charge. Contemporary accounts reveal the escalating level of despair among Ottoman Muslims as they watched their coreligionists suffer and encountered at first hand the victims of Christian atrocities. One account explains that the escalating series of crises facing the Empire made it feel as if 'A nation was disintegrating, sinking into the darkness of history... All we could do was... protest ... sing bitter marches and shout 'vengeance, vengeance.' 24 This vengeance was to be against Christians, those perceived to be the cause of the Empire's decline, and the greatest threat to its continued survival.

The solution, in the minds of European and Turkish diplomats, was to institute an exchange of populations, one which would physically separate Christians from Muslims in Greece and Turkey alike. Under the terms of the exchange, all members of the Greek Orthodox

\footnotetext{
${ }^{21}$ Nicholas Doumanis, Before the Nation: Muslim-Christian Coexistence and Its Destruction in Late Ottoman Anatolia (Oxford: Oxford University Press, 2013), 49.

${ }^{22}$ Benjamin Braude and Bernard Lewis, Christians and Jews in the Ottoman Empire: The Functioning of a Plural Society (New York: Holmes and Meier Publishers, 1982).

${ }^{23}$ Ahmet Akgündüz, 'Migration to and from Turkey, 1783-1960: Types, Numbers and Ethnoreligious Dimensions,' Journal of Ethnic and Migration Studies 24, no. 1 (1998): 100.

${ }^{24}$ Ahmed Hamdi. Başar, Ahmet Hamdi Başar'in Hatiralari, ed. Murat Koraltürk (Istanbul: Istanbul Bilgi Universitesi, 2007), 75-77.
} 
religion living in Anatolia, a population that had once numbered 1.3 million, were forcibly relocated to Greece, and they were banned from ever returning. ${ }^{25}$ In exchange, 400,000 Muslims living in Greece were relocated to Turkey. In reality, a mass exodus of Greek Orthodox Christians had already significantly depleted the Greek population in Anatolia, and the sudden influx of refugees severely taxed resources in Greece. The relocation of Greece's Muslims, in addition to homogenizing Greece itself, was seen as a way of 'making room' for the incoming refugees, though the significant disparity in numbers ensured that such an effort would not be nearly enough. ${ }^{26}$ While politicians involved expressed reluctance and regret over the exchange, many thought it was the only way to calm tensions in a contested region claimed by both states. The exchange was thus meant to homogenize both countries and remove 'minority elements that threatened the fledgling self-constructed historical narratives and national identities of the two states. $^{27}$

The idea for a compulsory population exchange was put forward by Fridtjof Nansen, the League of Nation's High Commissioner for Refugees. ${ }^{28}$ While an exchange of populations had been hinted at by several parties, neither Turkey nor Greece especially wanted to take the blame for proposing such a controversial solution. As Riza Nour, one of the Turkish delegates, explained in his memoirs 'we had wanted to put the population exchange forward, but did not dare to do so. ${ }^{, 29}$ Eleftherios Venizelos, the lead Greek delegate, publicly expressed his abhorrence for the idea, but he too may have been more supportive of exchange in private than he was willing to admit to publicly. Indeed, in the end, the agreement had the strong support of both national governments and the League of Nations, who believed that the separation of the two communities was the best course of action for both nations. ${ }^{30}$ Such sentiments were echoed by the beliefs of many on the ground in western Anatolia and even Greece, where the relationship between the two religious communities had deteriorated long past the point of saving.

Significantly, the population exchange, though supposedly meant to divide the population along national lines, was based exclusively upon religious affiliation and ignored the territorial, linguistic, and even ethnic factors that modern scholars have focused on as essential characteristics of national identities. ${ }^{31}$ The population exchange was carried out by a special Mixed Commission consisting of representatives from the Greek and Turkish governments, as well as from those of three neutral observers appointed by the League of Nations, and while questions immediately arose about the applicability of the agreement to various individuals and populations, it was strictly enforced. ${ }^{32}$ Christians were to be inhabitants of Europe, Muslims of

\footnotetext{
${ }^{25}$ Bruce Clark, Twice a Stranger: The Mass Expulsions That Forged Modern Greece and Turkey (Cambridge, Mass.: Harvard University Press, 2006), 12.

${ }^{26}$ Foreign Office Great Britain, 'Lausanne Conference on Near Eastern Affairs 1922-1923: Records of Proceedings and Draft Terms of Peace' (London: H.M.S.O., 1923), 185.

${ }^{27}$ Onur Yildirim, 'The 1923 Population Exchange: Refugees and National Historiographies in Greece and Turkey,' East European Quarterly. 40, no. 1 (2006): 45.

${ }^{28}$ Great Britain, 'Lausanne Conference on Near Eastern Affairs 1922-1923: Records of Proceedings and Draft Terms of Peace,' 123.

${ }^{29}$ Clark, Twice a Stranger: The Mass Expulsions That Forged Modern Greece and Turkey, 94.

30 Ibid.

${ }^{31}$ Great Britain, "Lausanne Conference on Near Eastern Affairs 1922-1923: Records of Proceedings and Draft Terms of Peace," 828.

32 Stephen P. Ladas, The Exchange of Minorities; Bulgaria, Greece and Turkey (New York: Macmillan, 1932).
} 
Turkey. This reliance on religion as a key marker of national identity caused significant problems for those whose other markers of ethnic and national identity did not match up with their religious identities. In Turkey, the Karamanlides, Turkish-speaking Greek Orthodox Christians from near Cappadocia in central Turkey, and Orthodox Arabs from Cilicia were compelled to emigrate to Greece despite their lack of any connection with Hellenic nationalist sentiments, ${ }^{33}$ while the majority of exchanged Muslims from Crete and elsewhere in Greece spoke only Greek, with no cultural or linguistic connection to their new ethnic 'homeland. ${ }^{34}$

Though it received the support of the major European powers and was counted as a political success for all countries involved, the Greco-Turkish population exchange was an unmitigated disaster for the religious minorities in both countries who were compelled to leave their homes. In Greece, which lacked the infrastructure and resources to care for the incoming refugees, exchangees piled up in port cities and islands. Thousands died of rampant diseases, malnutrition, and exposure. Turkey faced similar issues in settling the hundreds of thousands of Muslim refugees on former Greek lands that had already been taken over by neighboring Turks, although there the toll on economic production taken by the depopulation of the countryside and the decimation of a largely Greek middle class proved a larger issue. Populations on both sides were left destitute, stripped of possessions and property, with official efforts for recompense long delayed, when they arrived at all. In its efforts to disentangle religious populations, the GrecoTurkish Population Exchange privileged homogeneity and a politics of exclusion over the needs of refugee populations and geopolitical negotiations over humanitarian concerns.

\section{The 2016 EU-Turkey Agreement on Refugees}

The same Greek ports and islands that once served as landing places for Christians and displaced Greek Muslims once again host thousands of refugees. The Syrian civil war and the rise of the Islamic State have created turmoil throughout the Middle East, displacing millions in a refugee crisis that has been deemed the worst since World War II. ${ }^{35}$ United Nations statistics placed the number of Syrian refugees at 4.8 million in 2016, with another 6 million internally displaced within Syria itself. ${ }^{36}$ Syrians fleeing their homes have frequently made their way across the border to Turkey, which hosted the largest number of refugees at more than 2.8 million as of August 2016, ${ }^{37}$ and from there to Europe, braving a dangerous sea crossing to the Greek islands and mainland, or working their way by land through Istanbul and into the Balkans. Much as leaders from Greece, Turkey, and the League of Nations did in 1923, contemporary leaders have taken steps to address a complicated situation. Just as in that earlier crisis, European and Turkish leaders settled on an exchange of populations, albeit on a smaller and more individualized scale, designed to remove 'dangerous' populations and replace them with seemingly safer alternatives in a manner that privileges geopolitical concerns over the lives of the refugees involved.

\footnotetext{
33 Ibid., 379-83.

${ }^{34}$ Clark, Twice a Stranger: The Mass Expulsions That Forged Modern Greece and Turkey.

${ }^{35}$ United Nations High Commissioner for Refugees, 'Global Trends: Forced Displacement in 2015,' 2016, http://www.unhcr.org/576408cd7.

${ }^{36}$ United Nations Office for the Coordination of Humanitarian Affairs, "Syrian Arab Republic: Key Figures," 2016, http://www.unocha.org/syria.

${ }^{37}$ United Nations High Commissioner for Refugees, “UNHCR Syria Regional Refugee Response - Turkey," 2016, http://data.unhcr.org/syrianrefugees/country.php?id=224.
} 
The growing migrant crisis prompted a series of contentious negotiations. Both the European Union and the Turkish government were unwilling to bear sole responsibility for the refugees. The EU's negotiations with Turkey represented an effort to externalize the problem of migration, pushing it beyond the EU and relying on third country efforts to securitize Europe's borders. ${ }^{38}$ Engagement with Turkey allowed European politicians to keep migrants at an arm's length, providing a solution that confined migrants to Turkey rather than allowing their unchecked entrance into Europe. For Turkey, the deal provides financial support for dealing with the millions of refugees that have gathered in camps around the country. It has also given Turkey significant political leverage, allowing the Turkish government to extract concessions, including visa-free travel for Turks to EU countries and, most importantly, the revival and acceleration of talks regarding Turkey's entrance to the EU. Though both sides agreed to these terms, progress has been slow. Europe has been hesitant to enact its side of the deal and member states have balked at the prospect of allowing travel rights and, especially, admitting Turkey to the EU. Yet Europe's reticence to allow further migration has overcome even those doubts. Turkish President Recep Tayyip Erdoğan has repeatedly threatened to stop enforcing migration controls, allowing unrestricted migration from Turkish territory into Europe if the EU does not fulfill its obligations. The agreement that has served as an expedient political solution for Europe and Turkey has thus turned the refugee crisis into a political opportunity, rather than an issue of humanitarian concern.

Turkish efforts to extract concessions have been successful because of European fears of migrants. Of chief concern to Europe was the sudden influx of a population considered to be dangerous. Fears that the refugee population might conceal terrorists have mingled with a cultural and civilizational fear of the changes that might be wrought by large scale Muslim immigration. ${ }^{39}$ Indeed, the backlash against Syrian refugees is part of a larger trend of Islamophobia throughout Europe. ${ }^{40}$ Recent terror attacks committed by individuals claiming allegiance to the Islamic state in Belgium, France, the U.K. and Germany have produced an attitude of suspicion towards Islam and immigrants from the Middle East, who are often considered alien to the European way of life. In many ways, such sentiments produce an essentialized and negative view of Islam, one deemed irreducibly incompatible with what it means to be European and a part of Western civilization. ${ }^{41}$ Such anti-Muslim and anti-immigrant views have gained an increasing foothold in European society, and have buoyed the electoral success of far right-wing and nationalist organizations throughout the continent. ${ }^{42}$ For the European Union, the agreement thus provided an important opportunity to calm fears of a Muslim invasion, promising to limit to the number of refugees seeking refuge in Europe and assuaging Europeans traumatized by recent terrorist attacks. It also promised to lessen some of the crushing pressure of the tens of thousands of immigrants already in the EU, trapped at

\footnotetext{
${ }^{38}$ Anja Palm, “Did 2016 Mark a New Start for EU External Migration Policy, or Was It Business as Usual?," IAI Working Papers 16, no. 33 (2016).

${ }^{39}$ Pew Research Center, “Europeans Fear Wave of Refugees Will Mean More Terrorism, Fewer Jobs," July 2016.

${ }^{40}$ Andreas Zick, Beate Küpper, and Andreas Hövermann, Intolerance, Prejudice, and Discrimination - A European Report (Berlin: Friederich Ebert Stiftung, 2011).

${ }^{41}$ Mehdi Semati, 'Islamophobia, Culture and Race in the Age of Empire,' Cultural Studies 24, no. 2 (2010): $256-75$.

${ }^{42}$ Ferruh Yilmaz, "Right-Wing Hegemony and Immigration: How the Populist Far-Right Achieved Hegemony Through the Immigration Debate in Europe," Current Sociology 60, no. 3 (2012): 368-81.
} 
checkpoints in Greece after Balkan countries and others in Europe sealed their borders to incoming refugees.

As in 1923, Greece, a country already beset by severe economic problems amidst an ongoing debt crisis, was unprepared for the sudden influx of such a large refugee population. The tens of thousands of refugees that made it to Greece before the agreement found themselves in camps throughout Greece, where conditions soon became miserable. Little access to medical care and appalling hygiene conditions led to the proliferation of disease. The exchange has not improved these conditions much. Just as it was unprepared for the arrival of so many refugees, Greece lacks the infrastructure and support to adequately handle an exchange of this magnitude, leading to further misery for the refugees. Despite promises that asylum cases would be heard and applicants treated fairly, the rushed nature of the agreement, lack of translators, little access to legal advice, and an opaque asylum process has left thousands of refugees vulnerable to exchange. Contrary to assurances that all those eligible for asylum would be exempt from exchange, the first wave of migrants removed by European authorities included dozens who would have been eligible to apply. Many of them had expressed interest in the asylum process, but the lack of legal infrastructure available to refugees precluded them from making formal applications. ${ }^{43}$ The thousands of staff members promised by the EU to help process asylum requests and deal with the logistics of the exchange were late to arrive in Greece, leading to further confusion and negative outcomes for arriving migrants.

For those refugees sent back to Turkey, life rarely improves. While refugee camps in Turkey have better conditions than those in Greece, deportation back to Turkey takes refugees further from their ultimate goal of safety and a new life in Europe, free from the conflicts that drove them from their homes. Persistent allegations that Turkish authorities have rounded up hundreds of migrants and returned them to Syria do little to help matters. The situation has led Amnesty International to argue that 'In their desperation to seal their borders, EU leaders have willfully ignored the simplest of facts: Turkey is not a safe country for Syrian refugees and is getting less safe by the day. ${ }^{44}$ Yet, as in 1923, the insecurity and misery of the refugee population is entirely the result of policy. Rather than arising out of a lack of resources, the treatment of Syrian refugees has been the consequence of exclusionism and fear, as European countries struggle to turn back refugees they consider to be different, and potentially dangerous.

For all the contention that the negotiations over the fate of Syrian refugees has engendered, the agreement has been less successful than the parties might have hoped. While the flow of unauthorized refugees has diminished significantly, 2016 was the deadliest year in history for migrants of all origins seeking to cross the Mediterranean and Aegean to reach Europe. ${ }^{45}$ What the EU-Turkish Agreement has accomplished in limiting irregular migration to Europe has been balanced by its negative effect on refugee safety, as migrants turn to riskier and riskier pathways to the perceived safety of Europe. Moreover, the program exchanging

\footnotetext{
${ }^{43}$ Human Rights Watch, "EU/Greece: First Turkey Deportations Riddled With Abuse," April 19, 2016, https://www.hrw.org/news/2016/04/19/eu/greece-first-turkey-deportations-riddled-abuse.

${ }^{44}$ Amnesty International, "Turkey: Illegal Mass Returns of Syrian Refugees Expose Fatal Flaws in EU-Turkey Deal [Press Release]," April 1, 2016, https://www.amnesty.org/en/press-releases/2016/04/turkey-illegal-mass-returnsof-syrian-refugees-expose-fatal-flaws-in-eu-turkey-deal/.

45 United Nations High Commissioner for Refugees, "Mediterranean Death Toll Soars to All-Time High," October 25, 2016, http://www.unhcr.org/news/briefing/2016/10/580f1d044/mediterranean-death-toll-soars-2016-deadliestyear.html.
} 
unauthorized migrants for those officially registered in Turkey has exchanged far fewer migrants than have arrived in Greece. Between April and September of 2016, for example, 15,372 people arrived on the Greek islands, while only 578 were sent from Greece to Turkey. ${ }^{46}$ The agreement's lack of success in exchanging irregular migrants for those in Turkey highlights the political nature of the negotiations and the agreement's failure to adequately focus on the humanitarian aspects of the crisis. Politics of fear have driven European governments to seek the expulsion of a population some consider foreign and dangerous. Though the agreement to exchange refugee populations has been portrayed as a humanitarian effort to protect the lives of irregular migrants, it has struggled to live up to even its own rhetoric. The thousands of migrant deaths in the waters of the Mediterranean bear mute testimony to the power of an exclusionary logic that have driven European populations to privilege political expediency and sharply defined borders over humanitarian concerns and human rights.

\section{Conclusions}

In 1923, Greek, Turkish, and other European leaders crafted a population exchange that they promoted as a political and humanitarian victory, one that would protect the lives of minorities and lead to a greater era of peace and understanding between Turkey and Europe. In 2016, Turkish, and European leaders said much the same thing, extolling the virtues of an exchange theoretically designed to protect the lives of refugees and lead to a greater rapprochement between Turkey and the European Union. Both, however, had the final effect of removing unwanted populations of Muslims from European territory, enforcing civilizational boundaries that see Europe as reserved for Christians and the Middle East for Muslims.

Though they took place nearly a century apart, juxtaposing these two agreements reveals important similarities in the ways in which political actors conceptualized issues of identity, migration, and refugee movements. On one level, these similarities can be seen as the result of reiterative problem-solving by politicians who, faced with similar situations, devised agreements that would maximize political benefit and minimize their financial and humanitarian responsibilities toward refugees. More than this, however, both exchanges reveal historical sequences that reflected and reinforced particular social and political institutional patterns that helped differentiate Europe from outsiders. At its core, these patterns were driven by ontological narratives, historical stories that provided a coherent vision of European civilizational identity, one that drew upon memories of interreligious conflict to take Christianity as its organizing characteristic and view Islam as a foreign and unassimilable other. Though policy makers seem not to have learned lessons from the earlier exchange, the societies in which they live are in part structured by the collective memory of such exclusions.

Both exchanges thus represent the end result of a political process defined by its emphasis on exclusion and religious homogenization. In 1923, Turkey and Greece feared the continued presence of religious minorities deemed foreign to the nation. In 2016, European populations feared a similar population, deemed dangerous on account of religious affiliation. In this, institutional patterns structuring European identity have been strengthened and reaffirmed. The boundaries between Christian Europe and the Muslim Middle East that were reified by the first population exchange have been reinforced by European efforts to secure its borders against the influx of Muslims from Syria and the rest of the Middle East. Early Twentieth century

\footnotetext{
${ }^{46}$ Gerald Knaus, “Keeping the Aegean Agreement Afloat," Turkish Policy Quarterly, Fall 2016.
} 
political leaders sought a strict separation between Muslim and Christian populations, concerned that continued coexistence would lead to increased levels of violence. Conflict throughout the Middle East has once more caused turmoil throughout the region, and an influx of Muslim refugees have challenged the boundaries of Europe. Contemporary political movements in Europe have responded in much the way their predecessors did, arguing that the interaction between Muslim refugees and predominantly Christian Europe could bring with it only violence and conflict.

Yet the history of Muslim-Christian interaction in the Eastern Mediterranean brings with it important lessons for politicians and policy makers today. The devastating effects of the 1923 population exchange serve as a stark reminder that politics of exclusion and homogenization often bring with them immense humanitarian costs. Moreover, institutionalized patterns of religious exclusion have proved unsuccessful. Forcible separation did little to ameliorate conflicts between Christian and Muslim populations in the Middle East and Europe. Ontological narratives that place an emphasis on religious difference contrasted to a terrifying religious 'other' have merely heightened ideas of difference and incompatibility, helping to spur ideological and religious conflict. Such was the case in 1923, and it has been so again in 2016 when fears of terrorism and cultural decline have produced policies designed to separate Muslims from the protected boundaries of European civilization. In both cases, negotiations motivated by a politics of fear, civilizational difference, and political calculations have had a deleterious effect, helping to reinforce patterns of prejudice and religious conflict. Unless concerted action breaks the historical trajectory of civilizational difference, emphasizing humanitarianism over political calculation, refugee welfare over religious exclusion, the institutionalized patterns that have led to the deaths of thousands seem unlikely to change, reinforcing and extending a sad history of flawed refugee policies and leaving millions vulnerable. 